\title{
METAHADZIA UNCISPINA, A NEW AMPHIPOD FROM PHREATIC GROUND- WATERS OF THE GUADALQUIVIR RIVER BASIN OF SOUTHERN SPAIN*
}

\author{
by \\ JOS NOTENBOOM \\ Institute of Taxonomic Zoology, University of Amsterdam, P.O. Box 4766, 1009 AT Amsterdam, \\ The Netherlands
}

\begin{abstract}
Metahadzia uncispina n. sp. is described, being the second species of the genus on the Iberian Peninsula. The new species, well characterized by the transformation of the apical spine on the endopodite of the male uropod 2, is undoubtedly closely related with $M$. tavaresi (Mateus \& Mateus, 1972) from the south of Portugal. Comments are made about recent emendations of the original concept of the genus Metahadzia Stock, 1977.
\end{abstract}

\section{RESUMEN}

Se describe Metahadzia uncispina n. sp., la segunda especie de este género en la Península Ibérica. La nueva especie, bien caracterizada por la transformación de la espina apical del endopodito del uropodo 2 del macho, sin duda se relaciona estrechamente con $M$. tavaresi (Mateus * Mateus, 1972) del sur de Portugal. Además, se incluyen algunas consideraciones sobre correcciones conceptuales recientes relativas al género Metahadzia Stock, 1977.

\section{INTRODUCTION}

Hadziid Amphipoda are circumtropically distributed and occur in shallow marine and brackish waters or in fresh continental groundwaters at rather short distances of the actual coastlines. Largest taxonomic diversity of this cluster of amphipods is found in the greater Caribbean - Gulf of Mexico region (Holsinger, 1986). The Mediterranean region is another old Tethyan remnant in which hadziid amphipods are significantly distributed, although less diversified than in the first region.

The group is represented in the Mediterranean region by two genera, Hadzia $\mathrm{S}$. Karaman, 1932 and Metahadzia Stock, 1977.

\footnotetext{
* Groundwater crustaceans of Spain, 10.
}

Species of the genus Hadzia are distributed in the Dinaric karst of Yugoslavia along the Adriatic coast and in fresh continental groundwaters of Herzegovina, Montenegro, Macedonia and Bosnia (Karaman, 1969, 1984). Metahadzia is distributed in the eastern Mediterranean region along the Adriatic and Ionic coasts of Apulia, southern Italy (Pesce, 1979), and on the Ionic island of Cephalonia, Greece (Pesce, 1980). A western Mediterranean group of Metahadzia is found in the southern part of the Iberian peninsula.

Until now Metahadzia was represented on the Iberian peninsula by its type-species, $M$. tavaresi (Mateus \& Mateus, 1972) only, viz. from wells along the south Portuguese coast (Mateus \& Mateus, 1972; Stock, 1977). Investigations carried out in the basin of the Guadalquivir River revealed the existence of a new species of Metahadzia in shallow wells of the small village of Los Pajares in the province of Sevilla, Spain. These wells are fed by phreatic groundwaters in alluvial deposits of the Guadalquivir River at about $2 \mathrm{~km}$ from the main stream. In contrast to the other localities of the genus, the Spanish records lie at a rather large distance $(90 \mathrm{~km})$ from the coast.

\section{Metahadzia uncispina n. sp.}

Material examined. - Prov. Sevilla, Cantillana, well at the W. side of Los Pajares, just $S$. of road C 431 from Sevilla to Córdoba ( $=28 \mathrm{~km} \mathrm{N.N.E.} \mathrm{of} \mathrm{Sevilla),} \mathrm{UTM}$ coordinates TG495666, alt. $30 \mathrm{~m}$; 24 July 1984 (sta. 847/17), 1 o paratype, leg. J. Notenboom \& I. Meijers; temperature $22.2^{\circ} \mathrm{C}$, conductivity $1751 \mu \mathrm{S} / \mathrm{cm}$, oxygen $6.8 \mathrm{mg} / \mathrm{l}, \mathrm{pH} 6.69$, chlorinity $140 \mathrm{mg} / \mathrm{l}$. Accompanying fauna: Stenasellus, Cyclopoida, Harpacticoida, Ostracoda, Gastropoda (Pulmonata, Basommatophora), insects, and Oligochaeta. 
Prov. Sevilla, Cantillana, well at Los Pajares, UIM coordinates TG498670, alt. $30 \mathrm{~m} ; 30$ June 1985 (sta. A856/51), 1 o holotype, $1 \%$ allotype, 3 ơ $\sigma^{\circ}, 6 \%$, and 3 juvs. paratypes, leg. P. van den Hurk \& R. Leys; temperature $19.8^{\circ} \mathrm{C}$, conductivity $4900 \mu \mathrm{S} / \mathrm{cm}$, oxygen $6.9 \mathrm{mg} / \mathrm{l} . \mathrm{pH}$ 6.59. chlorinity $120 \mathrm{mg} / \mathrm{l}$. Accompanying fauna: Salentinella angelieri Ruffo Delamare Deboutteville, 1952, Stenasellus, Microparasellidae, Bathynellacea, Cyclopoida, Ostracoda, Gastropoda, and insects.

Prov. Sevilla, Cantillana, well at Los Pajares, UTM coordinates TG498670, alt. 30 m; 30 June 1985 (sta. A856/52), $1 \circ, 3$ 우, and 3 juvs. paratypes, leg. P. van den Hurk \& R. Leys; temperature $20.6^{\circ} \mathrm{C}$, conductivity 3600 $\mu \mathrm{S} / \mathrm{cm}$, oxygen $6.6 \mathrm{mg} / \mathrm{l}, \mathrm{pH} 6.58$, chlorinity $60 \mathrm{mg} / \mathrm{l}$. Accompanying fauna: Salentinella angelieri Ruffo * Delamare Deboutteville, 1952, Stenasellus, Ostracoda, Gastropoda, insects, and Oligochaeta.

Allotype from sta. A85-6/51 and male paratype of about $4 \mathrm{~mm}$ from sta. 84-7/17 completely dissected and mounted on slides in Faure's solution, holotype from sta. A85-6/51 partly dissected. All specimens preserved in the Zoölogisch Museum, Amsterdam (ZMA).

Description. - Length of male holotype 4.6 $\mathrm{mm}$ (without antennae and telson), largest male $4.8 \mathrm{~mm}$; female allotype $5.5 \mathrm{~mm}$, largest female $7.0 \mathrm{~mm}$. No females with setose oostegites present in the type series.

Male: Eyes totally lacking, body smooth and unpigmented. Interantennal sinus shallow. Antenna 1 (fig. 1c) about 3/4 of the total body length, peduncle sparsely setose, ratio of segments $2.0: 1.5: 1.1$. Accessory flagellum 2segmented, terminal segment less than half as long as basal segment. Terminal segment with single distal seta, basal segment with group of distal setae. Flagellum 27-segmented (paratype of $4 \mathrm{~mm}$ with 23 segments), segments with short distal setae, a single aesthetasc present on proximal segments and about as long as corresponding segment. Antenna 2 (fig. 1d) much shorter than antenna 1, peduncle with few short setae and slightly longer than peduncle of antenna 1 , peduncular segments 4 and 5 about of equal length. Flagellum 8-segmented, shorter than peduncle segments 4 and 5 together.

Upper lip with rounded apical margin. Corpus mandibulae (figs. 1e, f) asymmetrical, left molar seta lacking; palp (fig. 1e) well developed, ratio of segments 2.0:3.1:4.5, segments 1 and 2 unarmed, segment 3 covered with fine setules and with 5-7 apical and subapical setae, of which one distinctly longer, ventral margin unarmed. Maxilla 1: inner lobe with row of 9 medial setae, apex unarmed; outer lobe distally with 8-9, irregularly denticulate spines; palp 2-segmented, terminal segment asymmetrical, right wide and provided with 6 strong, blunt spines and 1 distolateral seta, left narrower with 6 slender distal or distomedial spines and 2 distal setae. Inner plate of maxilla 2 (fig. 1a) with oblique facial row of 14-17 setae, few medial and distolateral setae; outer plate slightly longer than inner plate. Lower lip (fig. 1g) wing-shaped, inner lobes absent, gap between the outer lobes Ushaped, distomedial parts of outer lobes covered with setae and fine setules. Maxilliped (fig. 1b): inner lobe slender, with 3 stout apical spines; outer lobe almost reaching to distal margin of palp segment 2, distomedially with 7 stout spines, lateral margin with row of spinules; palp slender, segment 2 with row of distomedial setae, segment 3 narrow at base, about as long as segment 2, segment 4 with 1 seta on lateral margin, unguis less than half as long as segment 4.

Gnathopod 1 with subquadrate coxal plate (fig. 1h), ventral margin with few setae, anterior margin with 6 setae. Merus (fig. 1i) with pilose posterior swelling, posterodistal group of setae with 1 longer, typically curved seta. Carpus about as long as propodus. Propodus rectangular with straight palmar margin, and pilosity on posterior and anterior surfaces. Palmar margin (fig. 1j) with small squamulae and a few setule-tipped spines, palmar angle with group of 2 longer bifid spines. Unguis about $1 / 3$ of length of dactylus.

Gnathopod 2 (fig. 2b) dissimilar to first. Coxal plate with rounded, poorly setose ventral margin, anterior margin rounded with 4 setae. Basis with some long setae along the posterior margin, anterior margin unarmed. Merus with only 2 posterodistal setae (one longer). Posterior surface of carpus pilose, the margin with 5 groups of setae, distal groups with longer setae. Propodus (figs. 2a, b) much stronger than that of gnathopod 1, with oblique palmar margin. 


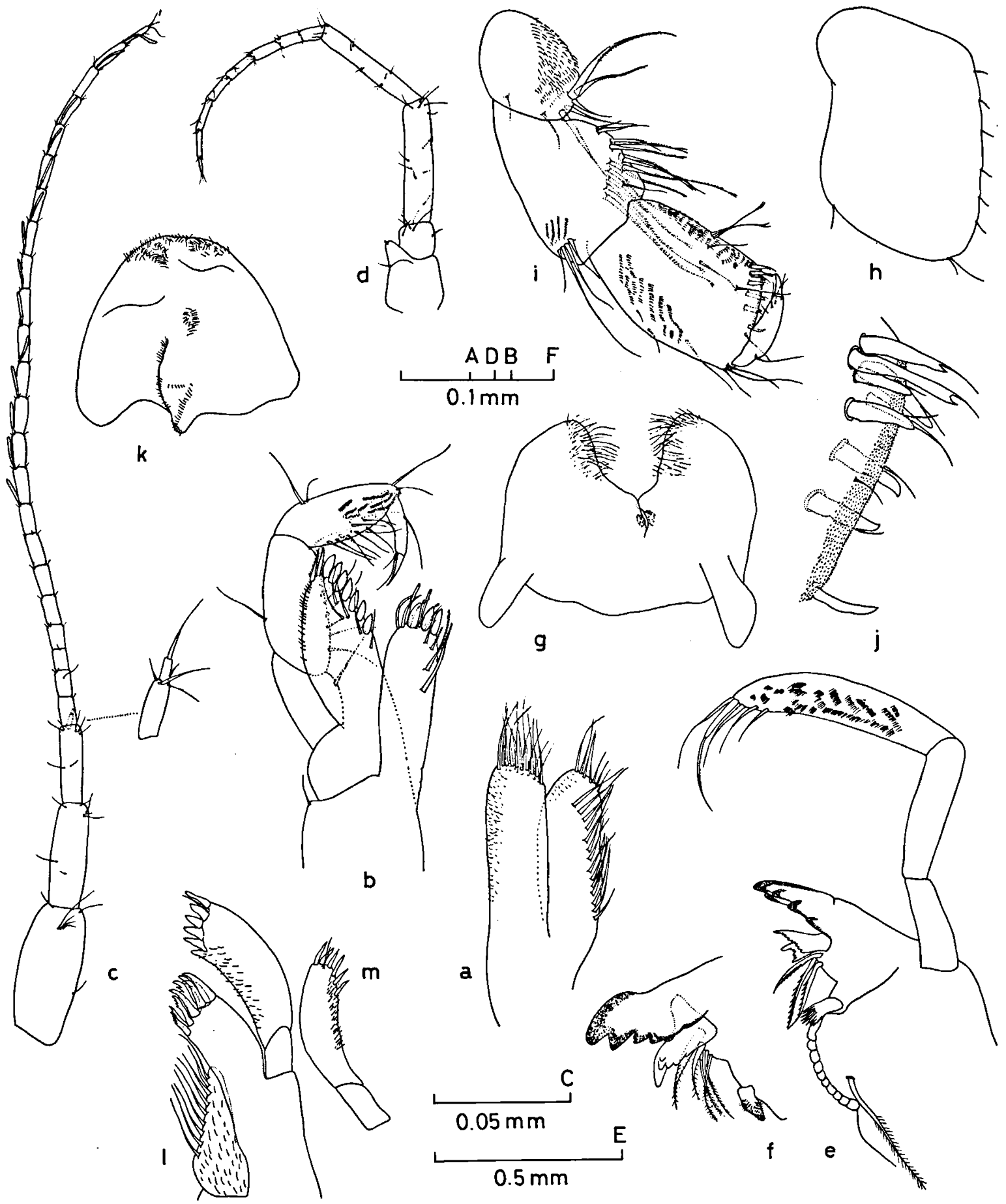

Fig. 1. Metahadzia uncispina n. sp., $\sigma^{\circ}$ holotype $4.6 \mathrm{~mm}$ : a, maxilla 2 (scale B); b, maxilliped (D); $\sigma^{\circ}$ paratype $4 \mathrm{~mm}$ : c, antenna 1 (E, detail scale F); d, antenna 2 (E); e, left mandible with palp (F); f, part of right mandible (F); g, lower lip (F); h, coxal plate 1 (A); i, distal part of gnathopod 1 (A); j, palmar margin gnathopod 1 (C); 9 allotype 5.5 mm: k, upper lip (F); l, maxilla 1 right (B); $\mathrm{m}$, palp of maxilla 1 left (B). 
Palmar margin with small squamulae and a row of setule-tipped spines on both inner and outer side. Palmar angle weakly delimitated by two longer setae. Inner side of dactylus toothed.

Pereiopods 3 (fig. 2c) and 4 of equal length. Ventral and anterior margins of coxal plate 3 rounded. Coxal plate 4 (fig. 2d) about as long as wide, posterior margin slightly excavate, ventral margin with 5 setae, and 2 anteroventral setae. Distal segments poorly spinous, claw rather short with unguis about half as long as dactylus. Coxal gills sack-like with welldemarcated stalk.

Pereiopods 5 to 7 (figs. 2e, f \& 3a): distal segments of posterior two pairs of pereiopods lacking in all specimens available. Coxal plates 5 and 6 anterolobate, plate 7 non-lobate. Basis of oval shape with well-developed posterior lobe, slightly overhanging in P5 and more strongly overhanging in $\mathrm{P} 7$, anterior margin with 5 (P5 and P6) or 4 (P7) spinules, posterior margin with 10 (P5 and P7) or 11 (P6) setules. Distal segments of pereiopod 5 (fig. 3a) poorly spinous, claw slender, unguis about 1/5 of length of dactylus.

Epimeral plates (fig. 3b): ventral margin of plate 1 straight, that of plates 2 and 3 slightly convex, unarmed except for slender anteroventral spine on plate 3 . Posterior margins slightly convex, with small setule on ventral half, posteroventral corners acute and pointed. Pleopods (fig. 2g): peduncle slender with 2 hooked retinacula dorsomedially; segment 1 of endopodite of pleopod 1 reaching up to the distal margin of segment 3 of exopodite, medially with a distally split seta. Pleopod 3 not transformed.

Urosomites without dorsal spinules. Uropod 1 (fig. 3c) with strong and very long ecdysial spine on prepeduncle. Peduncle with basoventral spine similar to ecdysial spine, a row of 3 dorsal spines, 2 medial spines, 1 longer distomedial spine, and 2 distolateral spines (longest reaching up to $1 / 3$ of length of exopodite). Endopodite slightly shorter than exopodite with small proximolateral setule, 3 medial and 4 terminal spines, of which one very slender. Exopodite medially with 2 plumose setae, a single marginal spine, and 3 terminal spines, one of which very slender. Uropod 2 (fig. 3d): peduncle with comb of 8 distomedial spines, distolateral processus well developed, exceeding half the length of exopodite and provided with minute setules. Endopodite longer than exopodite with 4 medial spines and 5 apical or subapical spines; one of apical spines very strong and long, with tip transformed into hook. Exopodite with 1 medial spine and 4 apical or subapical spines of which 1 longer. Uropod 3 (fig. $3 \mathrm{e}$ ): peduncle medially with a basal setule and a spine, distally $1+2$ spines. Endopodite almost as long as exopodite, medial margin with row of plumose setae and some spines, distal part of lateral margin with 3 groups of 1 plumose seta and 1 or 2 spines, apex notched with a small setule, subapically 2 small spines. Exopodite 2-segmented, terminal segment about $1 / 5$ of length of basal segment, medial margin with row of plumose setae and 1 spine, distomedially 1 seta and 1 spine, lateral margin with 3 groups of 2-3 spines, distolaterally a group of 3 spines, terminal segment only with subapical setule.

Telson (fig. 3f) totally cleft, lobes completely separate, each about twice as long as wide, with convex margins. Medial and lateral margin with (1)-2 spines, apically 3 spines and a sensory setule, dorsal surface with long sensory setule.

Female: in most features similar to male, with exception of gnathopod 2 and uropod 2 . Propodus of gnathopod 2 (fig. 2h) resembling that of male but more slender and with palmar margin less oblique, armed with fewer spines. Uropod 2 (fig. $3 \mathrm{~g}$ ) with distomedial comb of 13 spines, medial ones longer, distolateral processus lacking, rami very similar to male but none of the apical endopodite spines transformed. Upper lip (fig. 1k) and maxilla 1 (figs. 1-1, m) figured.

Etymology. - The specific name uncispina proposed for this species is a contraction of the latin words uncus (= barbed hook) and spina (= spine), referring to the transformed spine on the male uropod 2. 


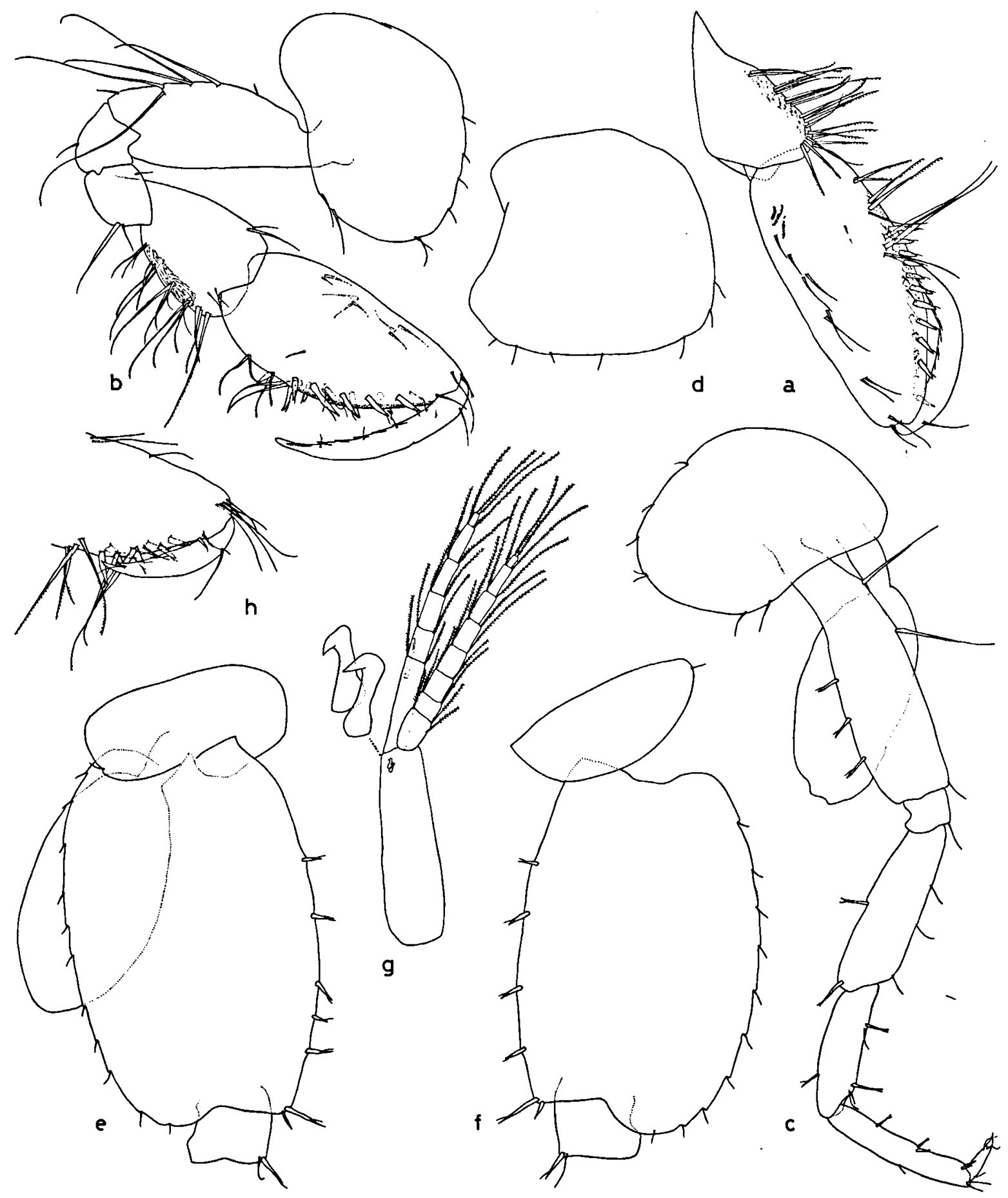

Fig. 2. Metahadzia uncispina n. sp., o holotype $4.6 \mathrm{~mm}$ : a, distal part of gnathopod 2 (scale A); $\sigma^{\circ}$ paratype $4 \mathrm{~mm}$ : b, gnathopod 2 (A); c, pereiopod 3 (A); d, coxal plate 4 (A); e, basis of pereiopod 6 (A); f, basis of pereiopod 7 (A); $g$, pleopod 1 (A, detail scale $\mathrm{C}$ ); $\&$ allotype $5.5 \mathrm{~mm}$ : h, distal part of propodus of gnathopod 2 (A). 
Remarks. - Metahadzia uncispina is very similar to $M$. tavaresi (Mateus \& Mateus, 1972) from the south of Portugal (Algarve). Both species share a sexually dimorphic uropod 2 which is a unique character not found in any other species belonging to the hadziid Amphipoda. Furthermore, the two species are identical in most of their remaining morphological features.

The most obvious difference is the transformed apical spine on the endopodite of the male uropod 2 in $M$. uncispina which is lacking in tavaresi. To be sure this important character has not been overlooked in previous studies (Mateus \& Mateus, 1972; Stock, 1977), material of $M$. tavaresi present in the collections of the Zoölogisch Museum Amsterdam has been reexamined. This included topotypes from a well at Tavira (coll. no. ZMA Amph. 107.004) and specimens from a deep well between Portimão and Laos (coll. no. ZMA Amph. 104.911). The latter locality is situated along the coast of the Algarve as well, but some $75 \mathrm{~km}$ more westward. My observations show indeed, in agreement with previous descriptions, the absence of a transformed spine on the male uropod 2 (figs. $3 \mathrm{~h}, \mathrm{i}$ ) in the Portuguese material. Moreover, males and females of $M$. tavaresi bear the typical distomedial comb of spines on the peduncle of uropod 2. This feature, also present in $M$. uncispina, has not been reported before. With respect to the armature of the peduncle of uropod 2 of $M$. tavaresi a probably intraspecific variability has been noticed. The only male topotype available in the ZMA collections possesses a dorsal row of strong spines which is lacking in the material from Portimão. The presence of these dorsal spines has not been mentioned in previous papers dedicated to this species (Mateus \& Mateus, 1972; Stock, 1977).

Close comparison of $M$. uncispina with tavaresi exhibits a number of additional differences. The morphological structures of $M$. tavaresi which are of importance in this context are figured by Stock (1977: figs. 5 \& 6). The female gnathopod 2 shows a concave palmar margin in $M$. tavaresi whereas it is convex in uncispina. The uropod 1 of $M$. uncispina has a pair of plumose setae on the inner margin of the exopodite, whereas both rami bear a rather long apical spine. In $M$. tavaresi these plumose setae are lacking and the apical spines are shorter. The shape of the telson lobes is very similar in both species, however in $M$. uncispina each lobe bears 1 or 2 lateral spines which are lacking in tavaresi.

\section{CONSIDERATIONS ABOUT THE GENUS METAHADZIA}

Metahadzia uncispina $\mathrm{n}$. sp. almost completely fits within the original diagnosis of the genus as given by Stock (1977), only exception being the presence of lateral spines on the telson lobes. Beyond question $M$. uncispina and tavaresi are closely related species. The protuberance of the peduncle developed in the male uropod 2 of the two species is a unique evolutionary novelty not encountered in any other amphipod. This apomorphic character clearly defines $M$. tavaresi and uncispina as a monophyletic group. The latter is a well-defined species owing to the autapomorphic transformation of the apical spine on the endopodite of the male uropod 2. Besides, $M$. uncispina exhibits a number of minor morphological characters by which it differs from tavaresi, but the phylogenetic significance of these are difficult to assess.

From the south of Italy Pesce (1979) described $M$. adriatica, whereas he considered Hadzia minuta Ruffo, 1947 as a member of Metahad$z i a$ as well. From the Greek island Cephalonia $M$. helladis was described next (Pesce, 1980). To include the Italian and Greek species in the generic concept of Metahadzia its definition was emended (Pesce, 1980). The diagnosis of Pesce is less unambiguous on the following points than the original definition of Stock (1977): (1) mandible palp segment 2 with or without some apical setae; (2) uropod 2 sexually dimorphic or not; and (3) telson lobes with or without lateral spines. In the widened concept of Pesce (1980) the sexually dimorphic uropod 2 is underestimated as an important autapomorphic character of the genus. However, Pesce might 


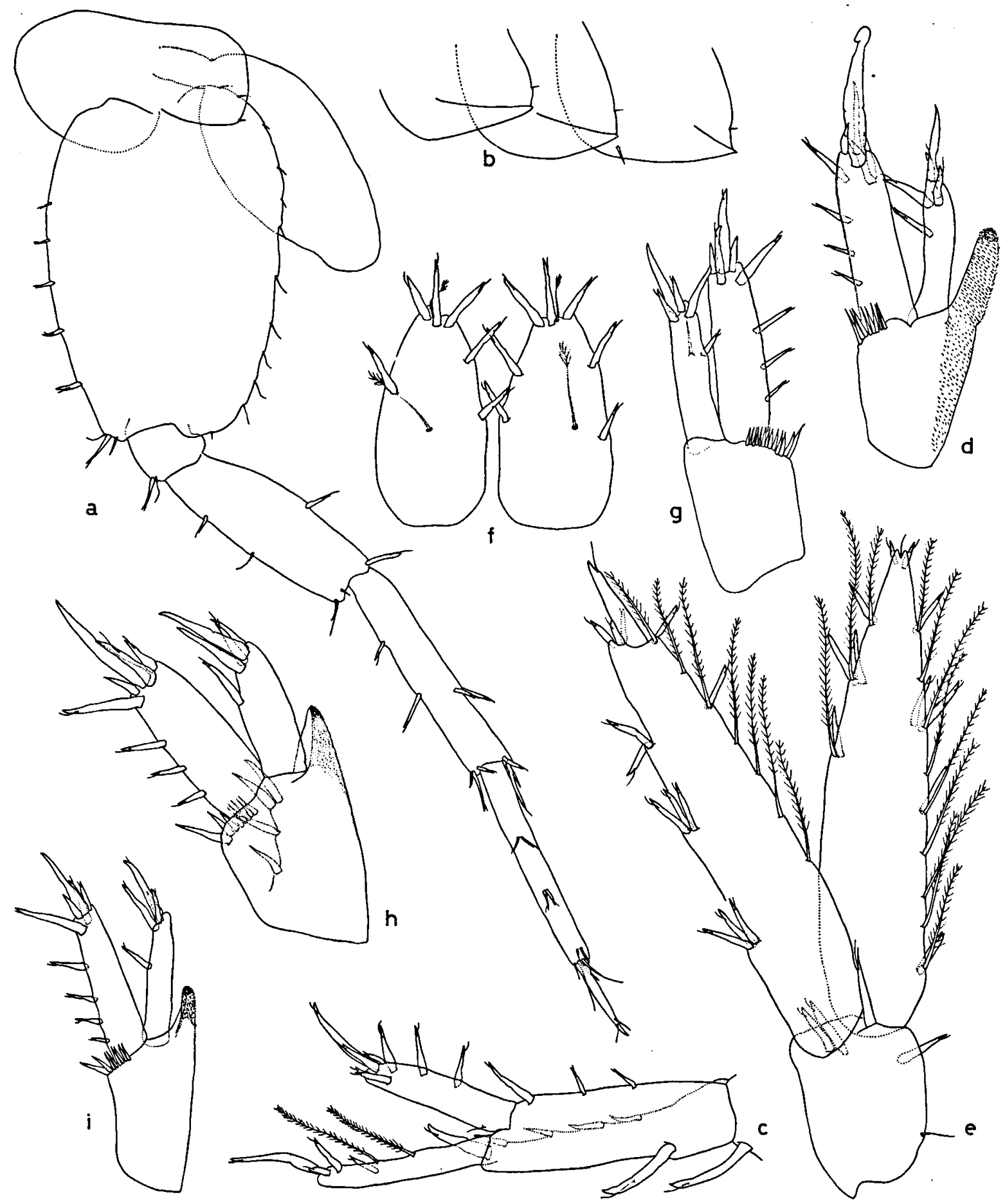

Fig. 3. Melahadzia uncispina n. sp., O' paratype $4 \mathrm{~mm}$ : a, pereiopod 5 (scale A); b, epimeral plates (B); c, uropod 1 (A); d, uropod 2 (A); e, uropod 3 (A); f, telson (A); 9 allotype $5.5 \mathrm{~mm}: \mathrm{g}$, uropod 2 (A). Metahadzia tavaresi Mateus \& Mateus, 1972, $\sigma^{\star}$ topotype $6.5 \mathrm{~mm}$ : h, uropod 2 (A); $\sigma^{\star}$ from Portimão: i, uropod 2 (A). 
be right in considering the presence of a few apical setae on segment 2 of the mandible palp and of lateral spines on the telson lobes of less diagnostic value on the generic level. Considering the armature of the telson in the sister species $M$. uncispina and tavaresi the lateral margins are found to be armed and unarmed, respectively.

The genus Metahadzia is considered to be very similar to Hadzia S. Karaman, 1932, Liagoceradocus Barnard, 1965 and Metaniphargus Stephensen, 1933. Although synapomorphies are unknown there seems to be little doubt in the amphipod literature about the close affinities between the members of this quartet (often named Hadzia complex or Hadzia sensu lato). However, the division of this cluster into taxonomic units is a considerable and frequently discussed problem. Karaman (1984) has reviewed this problem, as did Stock (1983) and Rondé-Broekhuizen \& Stock (1987).

The monophyly of Metaniphargus appears to be well established on arguments put forward by Stock (1983). Some of these arguments led Ruffo (1982) like Barnard (1977) to consider Metaniphargus a subgenus of Hadzia, while Stock considered them full genera. Stock (1985) distinguished a number of subgenera within Metaniphargus, for an important part based on different degrees in which sexual differences have been developed in pleopod 3 .

The diagnostic features of Liagoceradocus as outlined by Barnard (1977) are so weak that Ruffo (1982) considered it synonymous with Hadzia. Rondé-Broekhuizen \& Stock (1987), based on a redescription of $L$. acutus Andres, 1978 from Lanzarote (Canary Islands), bring up new arguments to distinguish Liagoceradocus as a separate entity. They consider sexual differences in the palmar armature of gnathopod 1 , a widened outer lobe of the maxilliped and the absence of plumose setae on uropod 3 as autapomorphic characters of Liagoceradocus which justify genus recognition. It remains questionable if the arguments of RondéBroekhuizen \& Stock (1987) are still valid when the other species of Liagoceradocus are reconsidered.
Within the Hadzia complex some morphological structures are developed that are not found in other amphipods and therefore probably can be considered as apomorphies: (1) the posterior lobe of the carpus of gnathopod 2 (Hadzia, Liagoceradocus), (2) a swollen proximal article of the inner ramus of male pleopod 3 (Metaniphargus partim), (3) the protuberance of the peduncle of male uropod 2 (Metahadzia partim), (4) a comb of distal spines on the peduncle of uropod 2 (Metaniphargus partim, Metahadzia partim). Some other characters are not uniquely developed and have probably a restricted phylogenetic importance within the Hadzia complex: (1) the 1-segmented accessory flagellum (Hadzia except $H$. pachypoda); (2) the short segment 1 of the peduncle of antenna 1 (Hadzia except H.pachypoda); (3) the absence of ventral setae on mandible palp segment 3 (Metahadzia). The latter set of apomorphies are based on reductions of more complex conditions found in other members of the Hadzia complex and in many other amphipod groupings. Apomorphies based on reductions can easily develop independently in separate phyletic lineages and might therefore not represent homologous conditions.

Ruffo (1982) described $H$. pachypoda from Somalia; in this species the gnathopod 2 is as in Hadzia and the remaining characters are as in Metahadzia. This combination of characters makes phylogenetic placement of this species difficult. However, the presence of the lobe on the carpus of gnathopod 2 is considered to be a stronger indication of phylogenetic placement of $H$. pachypoda with Hadzia than with Metahadzia. Consequently, the absence of ventral setation on mandible palp segment 3 is assumed to have developed twice, in Metahadzia and in $H$. pachypoda. One might wonder if the establishment of the genus Metahadzia sensu Pesce (1980) on the basis of a single rather weak autapomorphy is justified. Notwithstanding these considerations the new species of the Guadalquivir River basin described in this paper is classified in the same genus as $M$. tavaresi, type-species of Metahadzia, because they share the condition of the uropod 2 which is an important synapomorphy. 


\section{ACKNOWLEDGEMENTS}

The investigations of the author were supported by the Foundation for Fundamental Biological Research (BION), which is subsidized by the Netherlands Organization for the Advancement of Pure Research (ZWO).

\section{REFERENCES}

ANDREs, H. G., 1978. Liagoceradocus acutus sp. n., ein Gammaride aus der Jameos del Agua auf Lanzarote (Amphipoda, Crustacea). Mitt. hamb. zool. Mus. Inst., 75: 249-253.

Barnard, J. L., 1965. Marine Amphipoda of atolls in Micronesia. Proc. U.S. natn. Mus., 117 (3516): 459-552.

- - 1977. The cavernicolous fauna of Hawaiian lava tubes, 9. Amphipoda (Crustacea) from brackish lava ponds on Hawai and Maui. Pacif. Insects, 17 (2-3): 267-299.

Holsinger, J. H., 1986. Zoogeographic patterns of North American subterranean amphipod crustaceans. In: R. H. Gore \& K. L. Heck eds., Grustacean biogeography: 85-106 (A. A. Balkema, Rotterdam/Boston).

Karaman, G. S., 1969. XXI Beitrag zur Kenntnis der Amphipoden. Die Gattung Hadzia Kar. in Jugoslavien. Acta Mus. maced. Sci. nat., 11 (9): 163-177.

- , 1984. Contribution to the knowledge of the Amphipoda 133. New data on a genus Hadzia S. Kar. in Yugoslavia. Poljoprivreda i Šmarstvo, 30 (1): 13-31.

Karaman, S., 1932. Beitrag zur Kenntnis der SüsswasserAmphipoden, 5. Amphipoden unterirdischer Gewässer. Prirodosl. Razpr., 1: 179-232.

Mateus, A. \& E. De Oliveira Mateus, 1972. Une nouvelle espèce d'Hadzia (Crustacea, Amphipoda) du Portugal. Publicações Inst. Zool. Dr. Augusto Nobre, 117: 9-30.

Pesce, G. L., 1979. A new subterranean crustacean from southern Italy, Metahadzia adriatica n. sp., with notes on Hadzia minuta Ruffo (Amphipoda, Gammaridae). Bijdr. Dierk., 49 (1): 102-108.

- 1980. A new subterranean amphipod from Cephalonia, Greece, and taxonomic status of Metahadzia Stock 1977. Senckenbergiana biol., 60 (3/4): 271-276.

Rondé-Broekhuizen, B. L. M. \& J. H. Stock, 1987. Stygofauna of the Canary Islands, 4. Liagoceradocus acutus Andres, 1978, a blind anchihaline amphipod from Lanzarote: redescription, taxonomic status and occurrence. Bull. zool. Mus. Univ. Amsterdam, 11 (4): 25-37.

Rurfo, S., 1947. Hadzia minuta n. sp. (Hadziidae) e Salentinella gracillima n. gen. n. sp. (Gammaridae) nuovi Anfipodi troglobi dell'Italia meridionale. Studi Speleologia e Faunistici sull'Italia meridionale, 4. Boll. Soc. Nat. Napoli, 56 (Suppl.): 178-188.

- , 1982. Nuovi Anfipodi di acque sotteranee della Somalia. Monitore zool. ital., (N.S.) Suppl., 17 (3): 97-113.

Stephensen, K., 1933. Fresh- and brackish-water Amphipoda from Bonaire, Curaçao and Aruba. Zool. Jb., (Syst) 64: 415-436.

Srock, J. H., 1977. The taxonomy and zoogeography of the hadziid Amphipoda, with emphasis on the West Indian taxa. Stud. Fauna Curaçao, 55 (177): 1-130.

- - 1983. Amsterdam Expeditions to the West Indian Islands, Report 33. The stygobiont Amphipoda of Jamaica. Bijdr. Dierk., 53 (2): 267-286.

- - 1985. Amsterdam Expeditions to the West Indian Islands, Report 47. Stygobiont amphipod crustaceans of the hadzioid group from Haiti. Bijdr. Dierk., 55 (2): 331-426. 